\title{
Equity and Music Education: Euphemisms, Terminal Naivety, and Whiteness
}

\author{
Juliet Hess \\ Michigan State University
}

In this paper, I advocate for the use of explicit language for discussions of race and call for music education to move out of terminal naivety (Vaugeois 2013) toward a heightened consciousness of political issues and racial oppressions. Employing critical race theory (CRT) as a theoretical framework, this paper examines race-related silences and the importance of using direct language to identify structural and systemic racism. I offer practical suggestions for initiating "race talk" in school music, in postsecondary music education, and in music education scholarship. These practical implications emerge from the experiences of four Toronto teachers who participated in a multiple case study on social justice and anti-racist work in music education (Hess 2013), the literature on race and silencing inside and outside music education, and my own experiences as a former public school music teacher and music teacher educator. With the surge of hate crimes and unmasked white supremacy in the United States following the election of Donald Trump, ${ }^{1}$ being explicit about race is urgent. In this paper, I put forward ways that music educators can center issues of race and racism in daily praxis.

Keywords: race, racism, social justice, silence, music education

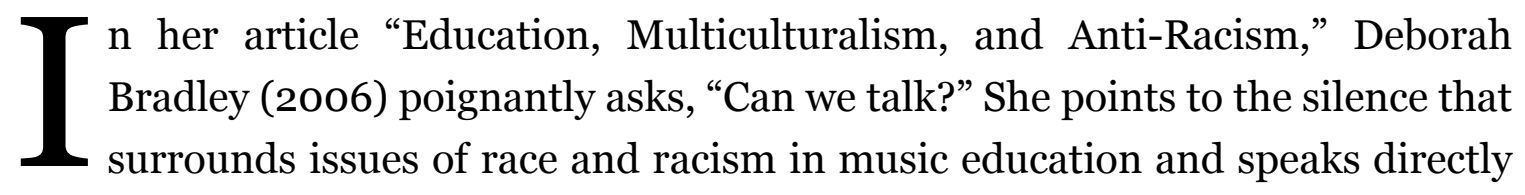
to the coded language that masks these issues in music education discourse, citing silence, fear, and discomfort as motivators for avoiding direct language. In the now more frequent calls for "diversity" and "social justice"2 in music educa- 
tion, 3 it is increasingly apparent that when our field is asked to speak of race that we4 begin to speak in euphemisms.

As a field, when we talk of race, we often clothe it in what Angelina Castagno (2014) calls "neutral concepts"-discussion that includes "similarities and differences, cultural factors, learning styles." We issue open directives, calling for teachers to adapt their curricula and teaching strategies and to develop strategic plans (Castagno 2014, 3). In doing so, we offer vague concepts to "purportedly address an issue (inequity) that is specific, concrete, and pervasive" (3). A euphemism substitutes an "agreeable or inoffensive expression for one that may offend or suggest something unpleasant" (Merriam-Webster n.d.). An open directive such as "adapting curriculum," for example, is nebulous. More specific language might ask educators to adapt curriculum to prioritize Afrocentric music, history, and perspectives. 5 Educators might reframe a call for "diversity" among music teachers to target the recruitment and retention of specific populations underrepresented in music education and work to address admission policies that limit access to postsecondary music teacher education programs by populations of color (Koza 2008).

Employing critical race theory (CRT) as a theoretical framework, this paper explicitly examines race-related silences and the importance of using direct language to identify structural and systemic racism. Drawing on literature from education, CRT, and music education, I explore the manner in which coded language and race-related silences operate in order to think about what it might mean to come to race consciousness in music education. I trace the "normative" model of music education to its historical roots in whiteness and ultimately offer practical suggestions for rupturing the dominant ideology of white supremacy, defined as the system of domination that systemically and structurally privileges White people and subjugates Others both discursively and materially (Mills 1997). ${ }^{6}$ I suggest rupturing white supremacy as it operates in music education through initiating "race talk" in school music, in postsecondary music education, and in music education scholarship. These practical implications emerge from the experiences of four Toronto teachers who participated in a multiple case study on social justice and anti-racist work in music education (Hess 2013), the literature on race and silencing inside and outside music education, and my own experiences as a public school music teacher and music teacher educator. 


\section{Critical Race Theory as an Analytical Tool for Music Education}

Critical race scholars Delgado and Stefancic (2001) put forward core principles of CRT. They identify CRT as a tool to critique liberalism and Eurocentrism that focuses on intersectionality and counternarratives. They argue that CRT provides an analytical tool to critique power and dominance and unmask power relations.

As a critical framework, CRT allows scholars to

understand how a regime of white supremacy and its subordination of people of color have been created and maintained in America, and, in particular, to examine the relationship between that social structure and professed ideals such as "the rule of law" and "equal protection." (Crenshaw et al. 1995, xiii)

CRT serves as a tool for the "deconstruction of oppressive structures and discourses, reconstruction of human agency, and construction of equitable and socially just relations of power" (Ladson-Billings 1998, 9). To analyze systemic issues in music education, I focus on three facets of CRT as sites for analysis throughout this article: the critique of institutional and systemic injustice, the critique of Eurocentrism, and the critique of whiteness 7 and white supremacy as a dominant ideology. CRT foregrounds race as a site for analysis, and this paper also takes that approach. To consider issues of language use, whiteness, and "terminal naivety" (Vaugeois 2013) - a term I explicate later-in music education, CRT allows music educators to recognize the whiteness and Eurocentricity present in school music at all levels and the ways in which masking systems serve to perpetuate these facets of institutions. A CRT framework with a focus on the critique of Eurocentrism, for example, facilitates the critique of and challenge to ensemble repertoire solely composed by White men. Identifying the Eurocentric patriarchy that influences repertoire choices in many bands, orchestras, and choirs enables music educators to become more intentional about including women and people of color among the composers they select for their ensembles. These ideas from CRT underpin the review of the literature and the subsequent practical discussion.

\section{Coded language and resounding silence: The complexities of race as "undiscussable" and the question of "terminal naivety"}

Pervasive silence surrounds the subject of race in music education (Bradley 2006, 2007) and education more broadly (Diem and Carpenter 2013; Kraehe 2015; Ladson-Billings 1996, 1998; Pollock 2004; Vass 2013)-an issue that is simulta- 
neously systemic and embedded in human actions. Ladson-Billings (1996) asserts:

My attempt to reposition race on the multicultural agenda is not an argument to substitute one single explanation strategy for another. Rather, I want to examine the ways that race, a social construct with powerful social and political implications, has been muted in the current multicultural paradigm or pitted against other subjectivities-particularly class and gender-to render it "undiscussable" as a difference or a site of struggle. (249)

The idea of race as "undiscussable" emerges repeatedly in the literature (Applebaum 2010, Bradley 2006, Diem and Carpenter 2013, Gill 2002, Kraehe 2015, Mazzei 2011, Mohan 2011, Pollock 2004, Sanchez-Hucles and Jones 2005, Vass 2013). Mica Pollock (2004) identifies the phenomenon as "colormuteness," arguing that despite the often-good intentions of those who do not speak of race, the mechanism of "colormuteness" works to institutionalize whiteness as a dominant ideology. "Colormuteness" relates directly to colorblindness (Dei 2000, Wise 2010) and, in some ways, it is colorblindness' operationalization. Mazzei (2011) contends that

as whites, we learn over time not to talk about race, especially whiteness, or, more importantly, how to talk about race by not talking about it. Further, as women, we are carefully taught that our role, in fact our duty, is in many instances to maintain peace, maintain silence, to smooth the rough edges and to provide a calm surface that belies the raging waters beneath. (664)

Silence, then, is complicated. It is resplendent with good intentions. Elementary and middle school students I have taught readily avoided any mention of race in class discussion-choosing colorblindness perhaps to avoid offending their peers. They meant well. Applebaum (2010), however, points to the ways in which focusing on intentions masks how power works through discourse (94). When educators prioritize "meaning well" or good intentions over the effect of erasing race from discourse in these instances, we miss opportunities to consider what such erasure does both in our own language and in the language practices of the students we teach.

When we do talk of race, as a discipline, we use coded language (LadsonBillings 1996), discourses of colorblindness (Dei 2000, Wise 2010), and the myth of the meritocracy (Giroux 2006, Giroux and Giroux 2004). We use words like urban, at-risk, and diversity to mean something very specific. We do not, however, actually name what we mean by "urban" for example-a term that is decidedly 
classed and raced, but is cloaked in politeness, niceness (Castagno 2014), and good intentions (Applebaum 2010, Castagno 2014).

What Lise Vaugeois (2013) terms "terminal naivety" further complicates the classical music and postsecondary music education sphere. For Vaugeois, "terminal naivety" describes a lack of awareness of power relations, larger global dynamics, and an individualistic focus on self-improvement often associated with classical musicians. She describes this state as a

mode of being in which individuals are constantly engaged in forms of selfimprovement, divorced from any sense of the systems of governmentality that shape our and other people's lives. (217)

Effectively, "terminal naivety" describes the intent to stay unaware or disinterested in world events and the systems that shape our society. In the context of "terminal naivety," there is an implied political disinterestedness too often present in the classical music world and the culture of silence and silencing that politicized individuals often encounter in classical contexts. This political disinterestedness facilitates the circulation of discourses of colorblindness and meritocracy in postsecondary music institutions-discourses that erase the material realities of musicians of color in these spaces. These discourses both foster misrecognition and act to silence dissonant voices. Significantly, Vaugeois challenges: "What are the alternatives if we give up our investments in disinterestedness, our embodiments of naivety" (219)? How, amidst marginalization and pervasive silence might we imagine a different way forward? Silence and disinterestedness are an integral part of our discipline. They are intertwined with our musicianteacher beings and operate powerfully in the world.

\section{Naming systems and coming to consciousness: An intervention for music education}

Given U.S. national political events leading to the election of Donald Trump as President and following his election and inauguration, along with the circumstances in the United States' National Association for Music Education (NAfME) that led to the resignation of Michael Butera in spring 2016,8 it is clearly time for our field to step out of the realm of terminal naivety and stop talking in euphemisms such as "diversity" and "social justice." We need to start bravely identifying the issues of oppression that prevent us from moving forward. 
Music education currently operates through an ideology of white supremacy, and this ideology has historical roots in our discipline. In a revealing study on race and whiteness in music education curricula, Gustafson (2009) traces the history of music education from its genesis in American schools in the mid-180os through to the early 2000s. The curricular endeavor she describes is explicit in its intent at hegemony. Gustafson points to the shift, for example, from the traditional music education approach of vocal music instruction toward a music appreciation method in the 1890 os (Gustafson 2009, 104). Following this shift, Black music and Aboriginal music were simply absent from this music appreciation curriculum. By the 1920s, however, their newly designated place in the curriculum affirmed their subjugated status. Within curricula, these musics played the role of "primitive" music for the young grades, intended as the path to developing the sophisticated (White) listener schooled in the Eurocentric canon. These curricula framed Black and Aboriginal musics as "simple"-steppingstones toward the more "complex" Eurocentric musics. These so-called primitive musics did not make up the whole of the young curriculum, as an entire curriculum of Black and Aboriginal musics may have produced the opposite effect to the one desired. Gustafson argued that in positioning these musics on the margins in the younger grades while privileging Eurocentric content, the notions of white supremacy tied to "sophisticated" Western classical music maintained a Darwinian hierarchy all by itself (Hess 2013, 11). The continued focus in music education on Eurocentric musical traditions and Western classical ensemble-based learning, with other musics and musical structures situated around the periphery of the curriculum (Hess 2015a, Morton 1994), reinscribes these same notions of white supremacy presently. Bradley (2015) points to many of the ways that racism operates in music education in "plain sight." She argues that we need to recognize the ways in which color-blind racism (196-7), the myth of music as a universal language (196), and the luxury of ignorance (of race and racism) (195) operate in music education, identifying the ways in which curricula and concepts such as "authenticity" can be colonizing (198-201).

As a discipline, then, we need to start naming systems. The white supremacy ideology present in music education both historically (Gustafson 2009) and in current practice (Bradley 2006, 2007, 2015; Hess 2015b, 2016; Koza 2008; Vaugeois 2013) point to the importance of identifying these systems in music education. As noted earlier, Mills (1997) defines white supremacy as the domi- 
nant global ideology that discursively and materially privileges White people and subjugates Others both systemically and structurally. Mills contends that society is actually predicated on a racial contract-an "invisible" contract upheld by White people both consciously and unconsciously for the perpetual subjugation of non-White "subhumans" or "subpersons" and the consequent privileging of the White body. The racial contract upholds what Mills identifies as the unnamed political structure present in the world today-global white supremacy.

Smith (2006) brings great insight to the workings of white supremacy. She argues that there are three pillars of white supremacy: slavery/capitalism, genocide/capitalism, and orientalism/war. The logic of slavery/capitalism renders Black people inherently "slaveable" or commodities, although slavery now includes mechanisms such as the Prison Industrial Complex (Davis 2000), which legalizes slavery and criminalizes Black people. The logic of genocide in the genocide/capitalism pillar holds that Indigenous people must disappear, which facilitates the erasure of complicity in the colonization of the land. The third pillar, orientalism/war, follows the logic that deems Others (i.e. immigrants) as foreign threats to empire, thereby justifying a continual U.S. state of war. Smith (2006) argues that these three pillars alternate in a way that enables white supremacy to function continually.

When I discuss white supremacy, I do not mean the Ku Klux Klan, although the KKK is certainly a manifestation of the ideology of white supremacy. Rather, I refer to both a societal structure or system and an ideology that is selfperpetuating. Given the U.S. election of Donald Trump after a campaign filled with racist, misogynist, classist, heterosexist, and ableist discourse, ${ }^{9}$ and the open resurgence of unabashed white supremacists following the election (Giroux 2017, Thompson 2017), centering these issues for discussion is urgent. As hate crimes surge in the United States, music education must play a role in identifying and combatting the systems that marginalize specific populations.

\section{Interrupting what? "Normative" music education}

In many ways, "traditional" music education reinscribes hierarchical relations of class and race and supports the pervasive, dominant ideology of white supremacy. The Western ensemble paradigm is dominant within North American music education (Hess 2013). The teacher usually controls activities within a Western classical sensibility (Bartel 2004, xii-xiii). Curriculum content is largely a repli- 
cation of music created by someone else, rather than creating (Bartel 2004, xiixiv). As a result of the repertoire selected for study, teachers often privilege Western notation over the aural transmission approaches present in other musical practices. This paradigm of music education fosters students who perform existing notated music well but do not display proficiency in vernacular or nonWestern musics in school.

In music programs that operate through this model, students conforming to this narrow paradigm are validated while other students (often students of color) are frequently pushed out of music. Elpus and Abril (2011) report that at the secondary level, White students were "significantly overrepresented among music students, as were students from higher SES backgrounds, native English speakers, students in the highest standardized test score quartiles, children of parents holding advanced postsecondary degrees, and students with GPAs ranging from 3.01 to 4.0 " (128). Significantly, Gustafson (2009) also noted a 99\% attrition rate of African American students from school music. In looking to address the whiteness of music education, we must directly name the systems that create it.

This pushing-out of youth of color from school music occurs partially through validating practices that privilege Eurocentric epistemologies, while devaluing skills typically associated with Black musics such as improvisation, ${ }^{10}$ oral tradition, and movement (Hess in press). Institutions place value, for example, on still comportment in listening and performing music (Gustafson 2009), on Western standard notation and Western "elements" of music, and limit aural/oral learning to "acceptable" forms of aurality such as teaching by rote-ideas that are antithetical to musical practices in the majority of cultures outside the sphere of Western classical music. When teachers include musics beyond Western genres, they often engage these musics through the Western classical paradigm, utilizing notation and Western elements, for example, to teach musics that draw on different frameworks.

Over the past 40 years, however, music educators have worked to shift this normative model. Since the Tanglewood Symposium of 1967, music educators have widely called for an expansion of the content of music education to include popular music, "world music" (a euphemism for non-Western musics), and composition and creative projects in the curriculum. These efforts indeed note movement away from the Western classical paradigm (Abril 2003; Campbell 2002, 2008; Fung 1995; Lundquist 2002; Morton 2003; Schippers 2010; 
Quesada and Volk 1997; Volk 1993, 1998). This paradigm shift, however, like the movement in music appreciation Gustafson traces, often includes non-Western musics and Western popular musics on the periphery of the curriculum, in a manner that is frequently additive (Morton 1994, Abril 2003, Hess 2015a) and often celebratory. Wasiak (2009) critiques:

Thus far, the multicultural music education movement has been more about diversity and musical tourism than understanding the musical and cultural practices of another on any more than the most superficial of levels (Campbell, 2002). This is true for a variety of reasons: the facile appeal of exotic repertoire, the ease of pre-packaged instructional packages rather than the more difficult task of engaging culture-bearers in the transmission of musical and cultural knowledge, mistaken notions about the universality of music, limited training of music educators regarding the musical practices and traditions of cultures outside Western Traditions, and the transposition of Western values on to what constitutes good music. (Wasiak 2009, 213-14)

Moreover, the multicultural movement in education is often complicit in failing to name issues of race, racism, and meaningful difference. Castagno (2014) argues, "Multicultural education has become a weasel word to denote something that has to do with diversity in educational contexts but that fails to address inequity. As such, multicultural education is a nice way to engage diversity" (47). She contends that multicultural education typically either involves "powerblind sameness" (i.e. denying difference and erasing power hierarchies) or "colorblind difference" (i.e. "denying racial difference while recognizing other forms of difference") (48). Despite the strengths of the multicultural movement in music education, a "multicultural approach" does little to shift the celebratory discourse of inclusion toward a meaningful conversation about race, power, and difference (Bradley 2006). Although "normative music education" in Canada and the U.S. often looks different than the Western classical ensemble model described above, these differences also reinscribe whiteness through superficial engagement with diversity and through failing to engage discourses of race and power.

\section{Breaking the Silence}

In the coded neoliberal discourse of music education, we fail to face the thundering whiteness of our field. Yet how do we begin to break the silence when "ignoring race is understood to be a graceful, even generous, liberal gesture" (Morrison 1990, 9)-even in the context of multicultural music education? As a discipline, how do we begin to speak truth to power, to reveal the whiteness of music educa- 
tion? In rendering race "undiscussable," the mirror we hold up to our discipline reflects only euphemisms-vague notions of diversity that mask systemic issues.

Steeped in notions from neoliberalism, music education advocacy discourses foster the idea that every child can do music and that music is a fundamental aspect of a child's education-a strategic discursive move that attempts to secure the place of music in schools. However, when we deploy these discourses, we fail to recognize that music education is far from neutral. We must continue to ask the questions that have prompted progress in music education following the Tanglewood Symposium in 1967. If "every child can do music," whose music do we mean? Which traditions? Which instruments? Then more powerfully, we must continue to ask who is not present in our classes, our programs, our curriculum, our pedagogy. Asking these questions over the last twenty years led to some significant changes in music education, including hip-hop pedagogy (Kruse 2016), popular music initiatives like Musical Futures, ${ }^{11}$ the honoring of informal music learning (Green 2001, 2008), and the push toward culturally responsive music teaching (Lind and McKoy 2016). As a discipline, asking these questions prompted shifts in curricula. In acknowledging the whiteness of secondary school music participation (Elpus and Abril 2011), ${ }^{12}$ for example, we can work to create a curriculum rooted in the musics intrinsic to the lives of youth beyond the confines of Western classical ensemble-based music programs, constructing our pedagogies to honor transmission and performance practices integral to their chosen musics. We ought, however, to be more deliberate and explicit.

In working to transform our curricula and pedagogy, music educators must also learn to speak in systems and power rather than in euphemisms. Current discourse often prioritizes inclusion-drawing people into the circle of music education who may not typically participate. Inclusive discourse, however, as Elizabeth Gould (2013) illuminates, is problematic. As we include more people and groups in music education, we do not change the core body of the discipline. When we work, for example, to "diversify" our ensembles and do so successfully, music education is not somehow less white. Furthermore, when music education draws in people from marginalized groups, these individuals may, in fact, remain marginalized in our discipline or, worse, be put in the position of holding up a mirror to music education to teach our field about its own whiteness. Instead, we must become self-reflexive and move beyond notions of inclusion to deep systemic questions. 


\section{Unbearable to Intolerable}

In a paper presented at last year's NAfME conference in Atlanta, Tami Draves (2016) called on our profession to think about the unbearable whiteness of music education. She drew upon Peggy McIntosh's (1988) now famous work on white privilege and mapped some of McIntosh's statements clearly into our field. As I listened in the audience-a room overflowing with people wanting to hear about whiteness in music education-the word unbearable struck me as not quite right. The "unbearable whiteness of music education" implies a lack of agency-a sentiment along the lines of "we cannot bear it, but we also cannot fix it." As Draves elucidated compellingly, as have others before her (Bradley 2006, 2007; Bradley, Golner, and Hanson 2007; Gustafson 2009; Hess 2013, 2014, 2015a; Koza 2008), music education is steeped in whiteness. I assert that we must reframe this "unbearability" and put forward the notion of the "intolerable whiteness of music education." "Intolerance" provides an imperative; it calls us to act. Acting begins with naming-with identifying systems clearly and then moving to dismantle them. As a discipline, if we are genuinely interested in what we call diversity, we must foreground issues of race, whiteness, and power, and then act accordingly.

\section{Getting Practical: Breaking the Silence in Music Education}

Given the "unbearable" whiteness of music education, this linguistic shift to "intolerable" necessitates action-action which our field resists due perhaps in part to the overwhelming nature of the systemic inequities embedded in most music education institutions. Breaking the silence about race and being explicit about our language (instead of masking our language in euphemisms) is crucial for addressing systemic inequities. This section addresses practical ways to prioritize race talk and name systems directly, first in the context of $\mathrm{K}-8$ schooling ${ }^{13}$ with students, and then with administrators and the community. I subsequently look at postsecondary opportunities, turning first to teacher education, followed by an examination of the postsecondary music education experience for all majors. I then address music education scholarship, and conclude with a discussion of language use beyond the classroom.

Hess, Juliet. 2017. Equity and music education: Euphemisms, terminal naivety, and whiteness. Action, Criticism, and Theory for Music Education 16 (3): 15-47. doi:10.22176/act16.3.15 


\section{Being Explicit with Students}

To think about explicit race talk in the context of $\mathrm{K}-8$ schooling, I reflect upon my doctoral work (Hess 2013) which, using the methodology of a multiple case study (Merriam 1998, Yin 2009), explored the discourses, philosophies, and practices of four elementary music educators who strove to challenge dominant paradigms in music education. The teachers' diverse practices included critically engaging with issues of social justice, studying diverse musics, introducing multiple musical epistemologies, contextualizing musics, considering differential privilege, and subverting hegemonic practices. While many themes arose in this research, the most significant theme considered the ways that teachers worked to actively challenge hegemonic paradigms through explicit race talk. This section explores the multifaceted ways through which four Toronto teachers, Amanda, Anne, Sarah, and Susan, ${ }^{14}$ engaged in this important work in order to think about ways that music teachers may take up this work in their classrooms. Amanda, Anne, Sarah, and Susan actively worked to challenge and subvert hegemonic paradigms through means that included making explicit connections between music and politics, naming race, challenging assumptions, and discussing equity issues in a curricular or personal manner. These strategies are instructive for K-8 educators who wish to actively address issues of race with students. The work of these teachers also has implications for secondary school teachers, who may draw upon similar strategies with older students.

First and foremost, the teachers worked to explicitly connect music to the political. Amanda, a first-year music teacher in a K-6 elementary school in a wealthy area of Toronto, Ontario, Canada, taught a predominantly White and affluent student population. As a White female music teacher with a particular interest in equity work, she purposefully connected classroom material to sociopolitical contexts and deeply contextualized all music studied. While I observed, her curriculum focused on African diasporic movement. With the students, she traced the Middle Passage to different landing points in the Americas. Her third grade class was just beginning this unit. They had studied Ghanaian music previously to set up the musics that followed. This excerpt is from the journal I kept during fieldwork:

Amanda begins the Grade $3^{15}$ class discussion by wondering how "so many musics have their roots in African music." The students volunteer answers; some answers involve travelling and Amanda builds on the idea. She asks the students what it means to be enslaved. One student says, "Holding someone 
against their will." "What does a person do if they're enslaved?" Amanda asks. "Do you get paid for the work you do?" Students shake their heads. She says people have estimated that 15 million Africans were taken and enslaved. She uses simple language that reflects the harshness of the topic nonetheless. She refers to enslavement as "kidnapping." People were "chained, forced to walk for as long as it took, sometimes for weeks. Europeans would overload the ships because some people would die on the way across." This class takes the discussion seriously and they talk about being treated like an object. She explains imperialism in simple terms, defining it as Europeans taking over the Americas and enslaving African people to make a profit. Amanda asks students to think about being enslaved and taken somewhere new. She talks about trying to preserve the culture from their place of origin. One of the students pointed out that there is still slavery. Amanda agrees and draws the distinction between the fact that it used to be legal, and now it's illegal. She says that just because slavery is illegal does not mean there is no racism. She notes that the most common connection to slavery now is child labor-a practice in which children are forced to work. She then connects the history back to the music: "Out of this terrible history, we see the strength of a culture." (Hess 2013, 285-6)

Amanda encouraged students to consider structural power relations and face historical and present realities of racism, enslavement, and colonialism. There were times, however, when the discussion was more problematic. In the same discussion in a different class, when faced with blatant oppression, the students discussed buying slaves and setting them free. They believed that faced with that situation, they would choose that course of action. In that context, as I discussed elsewhere (Hess 2015b), Amanda kept the conversation critical and challenged them: "But what if everyone else was doing it?" She pointed out the financial discrepancy and loss to students' own hypothetical plantations. Amanda did not allow students to say they would definitively not enslave; rather she encouraged them to understand that they would, at the very least, have been complicit (Hess 2015b, 85-6).

To provide a further example, the following lesson discussed the idea of a "code song." Amanda shared the history behind such songs, and the class worked through the words together:

Today, the Grade 3 students have to decode "Follow the Drinking Gourd"-a code song. The discussion is critical and insightful. Amanda explains the importance of the quail-a sign of spring. A student notes that in winter, your footsteps would be more noticeable. Another student offers that people living where it's warm might not know they "need warm clothes for winter, so spring would be better." Amanda asks about walking along the river. One student says, "The sound of the river will cover your sound and you can listen for the river so you know which way to go." The students agree that it would not be smart to walk on the road, as you'd be easily captured. And then a student interrupts: "I have

Hess, Juliet. 2017. Equity and music education: Euphemisms, terminal naivety, and whiteness. Action, Criticism, and Theory for Music Education 16 (3): 15-47. doi:10.22176/act16.3.15 
something to say. Canada wasn't a free country either. There just weren't plantations." Amanda responds immediately, "That's right. There was slavery here too. Slavery was made illegal in Canada before the States. But just because it was illegal didn't mean people couldn't be treated badly." The student continues, "That's right. And people are still sometimes treated badly." (The class consists of 14 White students and 1 Black student.) When the discussion moves into a critical direction, Amanda facilitates and asks them to think further. This is the first class where the students are critical of Canada. (Hess 2013, 288)

Vaugeois (2007) asserts that teachers often teach the official Canadian narrative of the Underground Railroad in which Canada is a "safe haven" to be congratulated for its moral superiority to the United States (175). Significantly, in her work with Afrocentric music with White students of privilege, Amanda did not encourage students to invest in this idea of "moral superiority." Rather, she made Canada's complicit role in slavery plain to the students. The explicit connection to politics occurred in other schools as well; it allowed for rich discussion of equity issues in music class. This type of contextual work connected musics to issues of political significance. Language was direct and spoke to systems and power-a key facet of CRT.

A second important aspect of this politically minded music education was explicit equity talk. This equity talk incorporated several themes-naming race and racism in both the classroom and the curriculum, and challenging assumptions. As Morrison (1990) stated, the "habit of ignoring race is understood to be a graceful, even generous, liberal gesture. To notice is to recognize an already discredited difference" (9-10). To name race explicitly is often considered controversial. "Race talk" and talk of other equity issues occurred most prevalently in the classes of Anne and Amanda, who were both explicit in their discussions. One issue that arose regularly was the students' notion that naming race was effectively synonymous with being racist, as this journal excerpt indicates:

The students discuss Celia Cruz and stumble over discussion of race. Amanda interjects: "Okay, saying someone is Black isn't racist. It's a fact." She talks about the words versus the actual color (i.e. she's more pink). (Hess 2013, 289)

Castagno (2014) also found that people frequently conflated naming race with racism.

Anne was a 12-year veteran teacher at Mills Road Junior Public School. The school district labeled Mills a "model school," coded language that indicated high socioeconomic need necessitating additional resources. The school neighborhood was relatively new, with little infrastructure, so the school served as the commu- 
nity center. Students at the school were largely first or second generation Canadians or new immigrants to Canada from low-income families. The majority of students were of African descent with a minority of East Asian, Brown, and White students. Anne took an explicit approach to issues of race, but there was also a nuanced aspect to her philosophy:

Anne: I'm hoping [anti-racism] is embedded in everything that I do... I believe that it happens naturally in the way that I teach because of my focus on justice with the students and my focus on multicultural music-and just my general philosophy. I hope it caters to that on its own. I believe that the kids come to school with a lot of learning that may have to be undone. And whether it's from the schoolyard or at home or society, 'cause there's certainly a lot of it everywhere. And we have to strive as educators, no matter what subject we're teaching, to try and break those barriers down in the ways that we teach.

Juliet: What kind of unlearning?

Anne: Unlearning. For instance, the student that came to me and said that Blacks should only be dating Blacks. Like, they didn't hear that from me. They've heard it from somewhere. I don't believe that an eight-year-old comes up with that on their own-so that kind of thing. We have to unteach that...right. So how do we go about that? So I think the way I do it is when I'm confronted with something like that or a similar issue in class or the boy who's in grade two wants to play with the pink My Ponies and gets teased for that. The way we handle that as teachers forms students' ideas around those concepts. So if I let it go, they're going to believe that it's okay. But if we stop and talk about it as a group, or if I go around the other way and teach the value of multicultural music without explicitly saying, "By the way, even though we look different and we come from different places we still share similar things." We attack it from both sides. Then I think we're helping students understand that there's a lot more to being a person than the color of your skin or the sex that you are or how smart or slow you are. So, I hope I'm attacking it from both sides. If it comes up in class, we deal with it, and the way I teach by taking turns and changing partners and multicultural music and things like that, I'm hoping that it's rounded. (Hess 2013, 289-90)

Anne had a two-tiered philosophy of anti-racism. She believed that her approach to multicultural music in the classroom fostered cultural understanding. She also advocated an explicit approach to addressing issues as they emerged. When a group of fifth grade girls informed a White student that she could not like a boy because he was Black, Anne abandoned music for a "more important issue." She introduced history into the discussion, and they had a deep conversation as a class. During that conversation, the class discovered that among the 30 members of the classroom community, 25 countries were represented through heritage. Anne pointed to the ways that the school celebrated those differences everyday 
while still acknowledging that there are important similarities between groups. In honoring both similarities and differences, Anne was careful not to erase or misrecognize students' identities. Instead, she recognized difference or heterogeneity within the larger whole.

Further to naming race and racism, teachers actively challenged students' cultural assumptions:

Another boy pointed to a boy who looked to be of East Asian heritage and made a comment about China. Anne asks why he thinks the boy is from China. She says that that would be like saying that she looks like she's from France just from looking at her. She tells the students you can't tell what part of the world someone is from just by looking. (Hess 2013, 291)

Anne worked to challenge students' assumptions about each other, actively countering the idea that it is possible to identify someone's heritage or ethnicity by appearance. When assumptions emerged, Anne worked to dispel them. She countered them, but also spent time explaining, so that students understood the issues.

Teachers were also explicit about the curriculum. Students in these four programs examined oppressions experienced by musicians of color, the practice of blackface in music contexts, issues of immigration and emigration, and larger political issues that related specifically to the "music as culture" studied. They also examined the origins of the musics studied. In many ways, these teachers explicitly addressed equity issues. They named race in their classes and pointed to oppression and equity issues as they arose. Moreover, they challenged students' assumptions about race in particular. Sometimes the discussions dealt directly with a problem that occurred; other times they were in relation to the curriculum, which they chose in order to create a space to have such discussions with their classes. They routinely engaged students in what Singleton and Linton (2006) refer to as "courageous conversations."

\section{Being Explicit with Teacher Discourse Outside the Classroom}

Outside of the classroom, in meetings with other teachers and administrators as music educators, we need to be more explicit about what we mean. Rather than speak in euphemisms, we need to name systems and speak directly about race, class, gender, sexual orientation, and disability. When I taught in the PreK-8 school setting, we would have full staff meetings led by administration at the 
beginning and middle of each semester, to identify students we deemed "at-risk." At-risk, in that context, typically identified a student struggling with language or math. These students were often students of color, and some faced significant socioeconomic barriers as well. Others were English language learners. As a staff, we used the non-explicit label "at-risk" to mask all of the systemic factors at play-to bury systems in "niceness" as Castagno (2014) elucidates in her study in Utah schools.

In masking our language, we individualized students in ways that were not particularly productive. Consistent with the meritocracy language of neoliberalism (Dei and Calliste 2000, Duggan 2003, Giroux and Giroux 2004), we pathologized the students (Harwood 2006) and failed to recognize the confluence of systemic racism, classism, ableism, sexism, and English language bias that affected them daily. Years later, I wonder how much more we could have accomplished if we instead had focused our attention on one or two systems that affected many of the students at the school and addressed them directly through additional programs or strategies. Pathologizing and individualizing students (Harwood 2006) allowed teachers to use "nice" language (Castagno 2014) to discuss students, but doing so did not ultimately serve the students well. As teachers, we can be explicit in our language with both our administrators and with other teachers and recenter discussion on systems when it becomes about individuals. These ideas in the K-8 context also apply to secondary schools.

When teachers recognize systems instead of faulting individuals in the community context, we create a unique opportunity for the school to work creatively with the community to address some of these issues collaboratively. Together we can think about programs that might address systemic disparities. We can draw on students' strengths in the community, in the models of culturally relevant pedagogy (Ladson-Billings 1995, 2009) and culturally responsive teaching (Gay 2010, Lind and McKoy 2016), to foreground what Yosso (2005) refers to as "community cultural wealth" and to implement specific strategies to address oppressions. In collaborating to identify the systems that target youth in schools, teachers can work to develop programs, policies, and strategies that relate directly to the challenges faced by the unique populations in their schools. 


\section{Teacher Education: Preparing for Courageous Conversations}

As music teacher educators, we must consider how to prepare teacher candidates for these "courageous conversations" (Singleton and Linton 2006), both in classrooms and beyond. Drawing upon the multiple case study with the four Toronto teachers, it is clear that sociohistorical and sociopolitical contextualization of music is an essential facet of being explicit with language. These four teachers actively addressed issues of oppression. They did so both within the context of the music studied through contextualization and through addressing issues of injustices and inequities as they arose in the classrooms. Teacher educators then need to model contextualizing class material and demonstrate locating all musics within a context in both ensemble and general music classrooms. We must also create opportunities for students to think through how they would handle a difficult conversation about injustice, perhaps through providing a case study ${ }^{16}$ for students to think through a hard situation and discuss it together with their peers.

Teacher educators can also encourage an awareness of world issues and their embeddedness in racism, inequity, and oppression, and the challenges youth face in our classrooms. Current local, national, and global events can and should be part of the quotidian conversation in teacher education. Fostering such awareness directly counters "terminal naivety" (Vaugeois 2013) in the classroom and instead urges future teachers toward a global consciousness important for teaching youth. It is also crucial to be direct with our own language as teacher educators, to explicitly name systems and encourage students to do the same. Discussing systemic issues and pointing to ways that educators often individualize and pathologize structural issues such as racism will help future educators recognize systemic issues as well as recognize coded language and individualizing discourses.

I currently teach a secondary general methods class for third and fourth year university students. In that class, we spend the first three weeks of the 15-week course discussing issues of equity and positionality. We focus on multiple facets of positionality-race, gender, disability, sexual orientation, and class-and consider how these facets of identity may explicitly affect the students in our classes and the way that we relate to specific groups, given our own positionalities and situatedness in the world. I argue that this type of education equips future teachers to have direct conversations about issues of equity, oppression, and 
injustice, and to directly name the factors and systems at work, using explicit language. Recognizing and naming systems and structures facilitates the ability to have "courageous conversations," both in the classroom and with other teachers and administrators.

\section{Postsecondary Music Study}

To think about postsecondary music study more broadly, as music educators we must focus our awareness on the demographics of postsecondary education and actively consider ways to identify the systemic issues that create these demographics. Naming systemic issues is an important step toward shifting these dynamics. Bowman (2007) offers a clear explanation of the pedagogical reinscription of the status quo, or more explicitly, the whiteness of music education. He notes that as music educators, we:

(1) Start with an understanding of music derived from and well-suited to one particular mode of musical engagement and practice. (2) Craft a definition of musicianship derived from its basic tenets and demonstrable primarily on instruments that have evolved in its service. (3) Privilege curricula and pedagogies that serve to nurture that kind of musicianship. (4) Select students for advanced study on the basis of criteria well-suited to these modes of practice. (5) Hire faculty to serve the needs and interests of such students. And (6) assess success in terms of the extent to which the norms and values of that tradition and its conventions are preserved. (Bowman 2007, 116, emphasis added)

As Bowman's fourth point illustrates, postsecondary music institutions in North America tend to cultivate a particular demographic of music student. ${ }^{17}$ Julia Koza (2008) argues that music schools often audition for students of a particular background. The necessity of private study over many years, and the classical music focus of many institutions, means that despite supposedly "colorblind" admission policies, students who audition successfully are often White, with some degree of socioeconomic means (at least enough means to sustain private study). As a result, the demographic of many postsecondary music schools is comprised of primarily White, middle class students-a phenomenon that continues into the university setting from high school music programs (Elpus and Abril 2011).

We must, as Julia Koza (2008) suggests, "listen for whiteness," not to fund it, but "to recognize its institutional presence, understand its technologies, and thereby work toward defunding it" (154). Talking about race and whiteness is 
crucial to moving in a different direction. We must stop talking in euphemisms and use direct language to identify the overt raced and classed issues inherent in the cycle that Bowman (2007) identifies. Participants in postsecondary music education must identify the ways that systems influence our programs, naming, for example, the strong presence of Eurocentricity in our curricula and an atmosphere of "terminal naivety" (Vaugeois 2013) in the conservatory model of music education.

\section{Scholarship: Naming Systems and Moving Away from Terminal Naivety}

Further to being more explicit with language at all levels of teaching, as music education scholars, we also need to use direct language in naming systems in our music education scholarship. Harper's (2012) work is instructive for thinking about explicit language in scholarship. He analyzed 255 journal articles on "campus racial climate, the experiences of minoritized persons at predominantly White institutions (PWIs), comparative studies of PWIs versus Historically Black Colleges and Universities (HBCUs), and studies that explored racial differences between Whites and minoritized persons" (13). Some of these articles drew specifically on a critical race (CRT) theoretical framework, but Harper noted that authors typically used "semantic substitutes" such as alienating, hostile, marginalizing, chilly, harmful, isolating, unfriendly, negative, antagonistic, unwelcoming, prejudicial, discriminatory, exclusionary, and unsupportive rather than overtly calling the campus climate racist (20). Authors diminished bolder statements by using softening words such as perhaps, may, might, possibly, could be, and presumably (16). The majority of the articles minimized race and racism as a determining factor in campus climate and experiences. ${ }^{18}$

Harper's (2012) work can inform music education scholarship. As peer reviewers and critical readers, we must become mindful of "softening" statements and the avoidance of direct language. Moreover, we can keep in mind that the use of particular theoretical frameworks, including CRT, often leads to pointed discussion that makes race salient in ways that have implications for music education. Harper's findings, when applied to music education, demonstrate a need to open up scholarship to encourage direct language pointing to the systemic and structural issues that music education both faces and perpetuates. Journal editors then have a responsibility to publish articles that use direct language that may perhaps make people uncomfortable, and allow for respectful responses and 
dialogue to those articles within the journals. Having direct conversations is crucial to moving forward as a field of practice, scholarship, and research in music education.

\section{Larger Manifestations of Coded Language}

In the wake of the events in Charlottesville, VA in August 2017 (Thompson 2017), the need for explicit language to describe current events becomes imperative beyond the classroom. In framing the ideology and practice of white supremacy as "white nationalism" or the "alt-right"19-a term coined by Richard Spencer in 2008 in the U.S. context-such language masks a dangerous ideology based on dehumanizing principles in the service of party politics. These euphemisms further obscure the ugliness of white supremacy and, moreover, position it as a viable alternative to other political positions. The naming of white supremacy directly disrupts the "alt-right's" jockeying for legitimacy. Given the widespread nature of this resurgence of so-called "white nationalism" (Marsh 2017, MacKinnon 2017, Nowak and Branford 2017, Taylor 2016), the need for direct language extends beyond music education to a daily practice in which we refuse to allow the masking of an ideology-one that is racist, Islamophobic, antiSemitic, heterosexist, anti-immigrant, anti-Indigenous, and ableist-that leads both to hate crimes and fatalities. ${ }^{20}$ Refusing a cloak of legitimacy to white supremacy through language practice represents a small step toward unsettling its viability as a political position. In any case, as music educators and as individuals concerned with justice and anti-oppression, we must now extend the use of direct language far beyond the classroom.

\section{Conclusion}

In considering the whiteness and terminal naivety (Vaugeois 2013) that abound in our field, it is clear that we must become more direct with our language and dispense with the use of euphemisms to mask systemic issues. With the surge of hate crimes and unabashed white supremacy in the United States following the election of Donald Trump, ${ }^{21}$ being explicit about race is an urgent matter. Educators must center issues of race and racism in their daily praxis, both inside and outside the classroom. A critical race analysis allows for the clear identification of systems and facilitates prioritizing the identification of systemic issues over the 
individualizing and pathologizing discourses typical of neoliberal music education. When we directly name the systemic issues operating at all levels of music education, we can work to address the issues in a manner that recognizes historical injustices, attempting to redress them in the present in a way that is meaningful to each community that participates in music education. As Castagno (2014) asserts, by avoiding direct language to name systems, we offer vague concepts to "purportedly address an issue (inequity) that is specific, concrete, and pervasive" (3). Refusing the cloak of terminal naivety (Vaugeois 2013) and using explicit language allows us to address injustices and oppressions directly, and to implement concrete and specific programs that work to address the "intolerable whiteness" of music education.

\section{About the Author}

Juliet Hess is an assistant professor of music education at Michigan State University, where she teaches secondary general methods in music education, principles in music education, and philosophy and sociology of music education. Juliet received her $\mathrm{PhD}$ in Sociology of Education from the Ontario Institute for Studies in Education at the University of Toronto. She previously taught elementary and middle school vocal, instrumental, and "world" music at a public school in the Greater Toronto Area. Her research interests include anti-oppression education, activism in music and music education, music education for social justice, and the question of ethics in world music study.

\section{References}

Abril, Carlos R. 2003. Beyond content integration: Multicultural dimensions in the application of music teaching and learning. PhD dissertation, Music Education, Ohio State University.

Applebaum, Barbara. 2010. Being White, being good: White complicity, White moral responsibility, and social justice pedagogy. New York: Lexington Books.

Asante, Molefi Kete. 1991. The Afrocentric idea in education. Journal of Negro Education 60 (2): 170-80.

Bartel, Lee. 2004. Introduction: What is the music education paradigm? In Questioning the music education paradigm, edited by Lee Bartel, xii-xvi. Toronto, ON: Canadian Music Educators' Association. 
Benedict, Cathy, Patrick K. Schmidt, Gary Spruce, and Paul G. Woodford, eds. 2015. The [Oxford] handbook of social justice in music education. New York: Oxford University Press.

Bonilla-Silva, Eduardo. 2006. Racism without racists: Color-blind racism and the persistence of racial inequality in the United States. 2nd edition. Toronto, ON: Rowman \& Littlefield Publishers, Inc.

Bowman, Wayne D. 2007. Who is the "we"? Rethinking professionalism in music education. Action, Criticism, and Theory for Music Education 6 (4): 109-31.

Bradley, Deborah. 2006. Education, multiculturalism, and anti-racism-Can we talk? Action, Criticism, and Theory for Music Education 5 (2): 1-30.

Bradley, Deborah. 2007. The sounds of silence: Talking race in music education. Action, Criticism, and Theory for Music Education 6 (4): 132-62.

Bradley, Deborah. 2015. Hidden in plain sight: Race and racism in music education." In The [Oxford] handbook of social justice in music education, edited by Cathy Benedict, Patrick K. Schmidt, Gary Spruce and Paul G. Woodford, 190-203. New York: Oxford University Press.

Bradley, Deborah, Ronald Golner, and Sarah Hanson. 2007. Unlearning whiteness, rethinking race issues in graduate music education. Music Education Research 9 (2): 293-304.

Burnard, Pamela. 2000. How children ascribe meaning to improvisation and composition: Rethinking pedagogy in music education. Music Education Research 2 (1): 7-23.

Campbell, Patricia Shehan. 2002. Music education in a time of cultural transformation. Music Educators Journal 89 (1): 27-32.

Campbell, Patricia Shehan. 2008. Musician and teacher: An orientation to music education. 1st edition. New York: W.W. Norton and Company.

Castagno, Angelina E. 2014. Educated in whiteness: Good intentions and diversity in schools. Minneapolis, MN: University of Minnesota Press. 
Crenshaw, Kimberlé, Neil Gotanda, Gary Peller, and Kendall Thomas. 1995. Introduction. In Critical Race Theory: The key writings that formed the movement, edited by Kimberlé Crenshaw, Neil Gotanda, Gary Peller and Kendall Thomas, xiii-xxxii. New York: The New Press.

Davis, Angela. 2000. The prison industrial complex. Oakland, CA: AK Press.

Dei, George J. Sefa. 2000. Towards an anti-racism discursive framework. In Power, knowledge and anti-racism education, edited by George J. Sefa Dei and Agnes Calliste, 23-40. Halifax, NS: Fernwood Publishing.

Dei, George J. Sefa, and Agnes Calliste, eds. 2000. Power, knowledge and antiracism education. Halifax, NS: Fernwood Publishing.

Delgado, Richard, and Jean Stefancic. 2001. Critical Race Theory: An introduction. New York, NY: New York University Press.

Diem, Sarah, and Bradley W. Carpenter. 2013. Examining race-related silences: Interrogating the education of tomorrow's educational leaders. Journal of Research on Leadership Education 8 (1): 56-76.

Draves, Tami J. 2016. The unbearable whiteness of music education. National Association for Music Education Conference, Atlanta, GA.

Duggan, Lisa. 2003. The twilight of equality: Neoliberalism, cultural politics, and the attack on democracy. Boston, MA: Beacon.

Dunbar-Hall, Peter, and Kathryn Wemyss. 2000. Popular music and music teacher education: Relationships between course content and course design. Research Studies in Music Education 15 (December 2000): 50-57.

Elpus, Kenneth. 2015. Music teacher licensure candidates in the United States: A demographic profile and analysis of licensure examination scores. Journal of Research in Music Education 63 (3): 314-35. doi:10.1177/002242941 5602470

Elpus, Kenneth, and Carlos R. Abril. 2011. High school music ensemble students in the United States: A demographic profile. Journal of Research in Music Education 59 (2): 128-45. doi: 10.1177/0022429411405207.

Hess, Juliet. 2017. Equity and music education: Euphemisms, terminal naivety, and whiteness. Action, Criticism, and Theory for Music Education 16 (3): 15-47. doi:10.22176/act16.3.15 
Frej, Willa. 2017. Trump targets Muslims, refugees In new executive order issued on Holocaust Remembrance Day. The Huffington Post, January 27. http://www.huffingtonpost.com/entry/trump-bans-muslims-refugeesexecutive-order_us_588bcaf3e4bobo65cbbco7ed?i2du1kzud1cx9wwmi\&

Fung, C. Victor. 1995. Rationales for teaching world musics. Music Educators Journal 82 (1): 36-40.

Gay, Geneva. 2010. Culturally responsive teaching: Theory, research, and practice, edited by James A. Banks. 2nd edition, Multicultural Education Series. New York, NY: Teachers College Press.

Gill, Sheila Dawn. 2002. The unspeakability of racism: Mapping law's complicity in Manitoba's racialized spaces. In Race, Space, and the Law: Unmapping a White Settler Society, edited by Sherene Razack, 157-84. Toronto: Between the Lines.

Giroux, Henry A. 2006. Stormy weather: Katrina and the politics of disposability. Boulder: Paradigm Publishers.

Giroux, Henry A. 2017. White nationalism, armed culture and state violence in the age of Donald Trump. Philosophy and Social Criticism 43 (9): 887-910. doi:10.1177/0191453717702800.

Giroux, Henry A., and Susan Searls Giroux. 2004. Take back higher education: Race, youth, and the crisis of democracy in the post-Civil Rights era. New York: Palgrave Macmillan.

Gould, Elizabeth. 2013. Companion-able species: A queer pedagogy for music education. Bulletin of the Council for Research in Music Education 197: 6376.

Green, Lucy. 2001. How popular musicians learn: A way ahead for music education. New York, NY: Ashgate Press.

Green, Lucy. 2008. Music, informal learning and the school: A new classroom pedagogy. London, UK: Ashgate.

Gustafson, Ruth I. 2009. Race and curriculum: Music in childhood education. New York, NY: Palgrave Macmillan. 
Harper, Shaun R. 2012. Race without racism: How higher education researchers minimize racist institutional norms. The Review of Higher Education 36 (1): 9-29.

Harwood, Valerie. 2006. Diagnosing 'disorderly' children: A critique of behaviour disorder discourses. London: Routledge.

Hess, Juliet. 2013. Radical musicking: Challenging dominant paradigms in elementary music education. $\mathrm{PhD}$ dissertation, University of Toronto.

Hess, Juliet. 2014. Troubling whiteness: Navigating white subjectivity in music education. International Society for Music Education (ISME) 2014, Porto Alegre, Brazil, July 20-25, 2014.

Hess, Juliet. 2015a. Decolonizing music education: Moving beyond tokenism. International Journal of Music Education 33 (3): 336-47.

Hess, Juliet. 2015b. Upping the "anti-": The value of an anti-racist theoretical framework in music education. Action, Criticism, and Theory for Music Education 14 (1): 66-92.

Hess, Juliet. 2016. Interrupting the symphony: Unpacking the importance placed on classical concert experiences." Music Education Research 18 (3): 1-11. doi: $10.1080 / 14613808.2016 .1202224$

Hess, Juliet. in press. Musicking marginalization: Periphractic practices in music education. In The Palgrave handbook on race and the arts in education, edited by Amelia M. Kraehe, Rubén Gaztambide-Fernández, and B. Stephen Carpenter II. Palgrave.

Koza, Julia Eklund. 2008. Listening for whiteness: Hearing racial politics in undergraduate school music. Philosophy of Music Education Review 16 (2): $145-55$.

Kraehe, Amelia M. 2015. Sounds of silence: Race and emergent counternarratives of art teacher identity. Studies in Art Education: A Journal of Issues and Research 56 (3): 199-213. 
Kruse, Adam. 2016. Toward hip-hop pedagogies for music education. International Journal of Music Education 34 (2): 247-6o. doi: 10.1177/0255761414550535.

Ladson-Billings, Gloria. 1995. Toward a theory of culturally relevant pedagogy. American Education Research Journal 32 (3): 465-91.

Ladon-Billings, Gloria. 1996. "Your blues ain't like mine": Keeping issues of race and racism on the multicultural agenda. Theory into Practice 35 (4): 248-55.

Ladon-Billings, Gloria. 1998. Just what is critical race theory and what's it doing in a nice field like education? Qualitative Studies in Education 11 (1): 7-24.

Ladson-Billings, Gloria. 2009. The dream keepers: Successful teachers of African American children. 2nd edition. San Francisco, CA: Jossey-Bass.

Lind, Vicki L., and Constance L. McKoy. 2016. Culturally responsive teaching in music education: From understanding to application. New York: Routledge.

Lundquist, Barbara R. 2002. Music, culture, curriculum, and instruction. In The new handbook of research on music teaching and learning, edited by Richard Colwell and Carol Richardson, 626-47. New York, NY: Oxford University Press.

MacKinnon, Mark. 2017. Trump of Europe's far right? Not quite-he's learned how to play nice. The Globe and Mail, January 5. Accessed June 11, 2017. https://www.theglobeandmail.com/news/world/is-austrias-norbert-hof...feuropes-far-right-no-hes-learned-how-to-benice/article31792343/.

Marsh, Stefanie. 2017. "This is exactly what he wants": How Geert Wilders won by losing. The Atlantic, March 16. https://www.theatlantic.com/ international/archive/2017/03/geert-wilders-won-by-losing-netherlandsvote/519834/.

Mazzei, Lisa A. 2011. Desiring silence: Gender, race and pedagogy in education. British Educational Research Journal 37 (4): 657-69. 
McCord, Keryl. 2016. Why we must have inclusion, diversity, and equity in the arts: A response to the National Association for Music Education. Alternate Roots, May 4, 2016. https://alternateroots.org/why-we-must-have-inclusiondiversity-and-equity-in-the-arts-a-response-to-the-national-association-formusic-education/

McIntosh, Peggy. 1988. White privilege: Unpacking the invisible knapsack. Wellesley, MA: Wellesley College Center for Research on Women.

Merriam, Sharan B. 1998. Qualitative research and case study applications in education. San Francisco, CA: Jossey-Bass Publishers.

Merriam-Webster. n.d. Euphemism. In Merriam-Webster Dictionary. https://www.merriam-webster.com/dictionary/euphemism.

Mills, Charles. 1997. The racial contract. Ithaca, NY: New York University Press.

Mohan, Erica. 2011. From cowardice to courage: Breaking the silence surrounding race in schools. Counterpoints 409: 53-62.

Morrison, Toni. 1990. Playing in the dark: Whiteness and the literary imagination. Cambridge, MA: Harvard University Press.

Morton, Charlene. 1994. Feminist theory and the displaced music curriculum: Beyond the "add and stir" projects. Philosophy of Music Education Review 2 (2): 106-21.

Morton, Charlene. 2003. In the meantime: Finding a vision for multicultural music education in Canada. In Looking forward: Challenges to Canadian music education, edited by Betty Hanley and Brian A. Roberts, 251-72. Toronto, ON: Irwin Publishing.

Nowak, Marysia, and Becky Branford. 2017. France elections: What makes Marine LePen far right? BBC News, February 10. Accessed June 11, 2017. http://www.bbc.com/news/world-europe-38321401.

O'Connor, Lydia. 2016. "Here are 13 examples of Donald Trump being racist." The Huffington Post, February 29, 2016. http://www.huffingtonpost.com/ entry/donald-trump-racist-examples_us_56d47177e4bo326obf777e83 
Perry, David. 2016. Trump's not just racist and sexist. He's ableist. Los Angeles Times, October 17. http://www.latimes.com/opinion/op-ed/la-oe-perrytrump-ableism-20161017-snap-story.html on January 27, 2017.

Pollock, Mica. 2004. Colormute: Race talk dilemmas in an American school. Princeton, NJ: Princeton University Press.

Quesada, Milagros. A., and Terese M. Volk. 1997. World musics and music education: A review of research, 1973-1993. Bulletin of the Council for Research in Music Education 131: 44-66.

Sanchez-Hucles, Janis, and Nneka Jones. 2005. Breaking the silence around race in training, practice, and research. The Counseling Psychologist 33 (4): 54758. doi: 10.1177/0011000005276462

Sarath, Edward. 2002. Improvisation and Curriculum Reform. In The new handbook of research on music teaching and learning, edited by Richard Colwell and Carol Richardson, 188-98. New York: Oxford University Press.

Sarath, Edward. 2013. Improvisation, creativity, and consciousness: Jazz as integral template for music, education, and society. Albany, NY: State University of New York Press.

Schippers, Huib. 2010. Facing the music: Shaping music education from a global perspective. New York, NY: Oxford University Press.

Singleton, Glenn E., and Curtis W. Linton. 2006. Courageous conversations about race: A field guide for achieving equity in schools. Thousand Oaks, CA: Corwin Press.

Smith, Andrea. 2006. Heteropatriarchy and the three pillars of white supremacy: Rethinking women of color organizing. In Color of violence: The Incite! anthology, edited by INCITE! Women of Color Against Violence, 66-73. Cambridge, MA: South End Press.

Taylor, Adam. 2016. The uncomfortable question: Was the Brexit vote based on racism? The Washington Post, June 25. https://www.washingtonpost.com/ news/worldviews/wp/2016/o6/25/the-uncomfortable-question-was-thebrexit-vote-based-on-racism/?utm_term $=.3654$ a9of58cc 
Thompson, Matt. 2017. The hoods are off. The Atlantic, August 12. https://www.theatlantic.com/national/archive/2017/08/the-hoods-areoff/536694/

Vass, Greg. 2013. Hear no race, see no race, speak no race: Teacher silence, Indigenous youth, and race talk in the classroom. Social Alternatives 32 (2): 19-24.

Vaugeois, Lise. 2007. Social justice and music education: Claiming the space of music education as a site of postcolonial contestation. Action, Criticism, and Theory for Music Education 6 (4): 163-200.

Vaugeois, Lise. 2013. Colonization and the institutionalization of hierarchies of the human through music education: Studies in the education of feeling. $\mathrm{PhD}$ dissertation, University of Toronto.

Volk, Terese M. 1993. The history and development of multicultural music education as evidenced in the Music Educators Journal, 1967-1992. Journal of Research in Music Education 41 (2): 137-55.

Volk, Terese M. 1998. Music, education, and multiculturalism: Foundations and principles. New York, NY: Oxford University Press.

Wasiak, Edwin B. 2009. Countering musical tourism and enacting social justice: Repositioning music education as a cross-cultural meeting place. In Exploring social justice: How music education might matter, edited by Elizabeth Gould, June Countryman, Charlene Morton and Leslie Stewart Rose, 212-24. Toronto, ON: Canadian Music Educators' Association/ L'Association canadienne des musiciens éducateurs.

Wise, Tim. 2010. Colorblind: The rise of post-racial politics and the retreat from racial equity. San Francisco, CA: City Lights Books.

Yin, Robert K. 2009. Case study research: Design and methods. 4th edition. Vol. 5, Applied social research methods series. Thousand Oaks, CA: SAGE Publications.

Yosso, Tara J. 2005. Whose culture has capital? A critical race theory discussion of community cultural wealth. Race Ethnicity and Education 8 (1): 69-91. doi:10.1080/1361332052000341006. 


\section{Notes}

${ }^{1}$ See the Southern Poverty Law Center "Hatewatch" website for hate incidents reported since the election of Donald Trump in the United States (https://www.splcenter.org/hatewatch).

2 I utilize scare quotes on the words "diversity" and "social justice" to call attention to the manner in which these terms serve as euphemisms for other concepts.

3 Conferences such as the "First International Conference on Equity and Social Justice in Music Education" at Teachers College, Columbia University in 2006, "musica ficta/Lived Realities: Engagements and Exclusions in Music, Education, and the Arts" at the University of Toronto in 2008, "Race, Erasure, and Equity in Music Education Conference" at the University of Wisconsin, Madison in 2010, the three "Symposia on LGBT Studies and Music Education" at the University of Illinois at Urbana Champaign, and "Musicking Equity: Enacting social justice through music education" at Michigan State University in 2017 bring issues of social justice and music education to the table, as do special issues in journals such as Music Education Research (MER), Gender, Education, Music, Society (GEMS), and Action, Theory, and Criticism for Music Education (ACT), as well as The Oxford Handbook of Social Justice in Music Education (Benedict et al. 2015).

4 Throughout this article, I use the word "we" to indicate all people interested in music education, and, more specifically, individuals who consider themselves music educators.

5 Afrocentricity centers African and African American perspectives instead of the Eurocentric focus typical of North American and Western European schooling (Asante 1991). This shift in perspectives allows other possible foci than Western European-centered education and work to center children in their own experiences before expanding to examine other perspectives. Afrocentric musics are musics rooted in Africa and span geographically both on the continent of Africa and across countries where Africans were enslaved (e.g. African American music, Afro-Brazilian music, Afro-Cuban folkloric music).

${ }^{6}$ I extend this definition later in this article.

7 I note here Mills' (1997) distinction between Whiteness as a political commitment to sustaining white supremacy and whiteness as phenotype/genealogy.

${ }^{8}$ Michael Butera, the former executive director of the National Association for Music Education (NAfME), attended a meeting on diversity, inclusion, and equity in the arts hosted by the National Endowment for the Arts with many other arts organizations. Individuals seated at his table noted that Butera asserted that "his 
board was all white and that he couldn't diversify his board because they aren't appointed but, rather, they are elected by the membership. Further, his membership isn't diverse because, 'Blacks and Latinos lack the keyboard skills needed for this field.' He also intimated that music theory is too difficult for them as an area of study" (McCord 2016). Upon allegedly making this overtly racist statement, Butera then vacated his seat at the table-effectively removing the major association of music education in the United States from an important conversation on equity. He resigned as executive directly a week later, succeeded by Michael Blakeslee.

9 See Frej (2017), O'Connor (2016), and Perry (2016) for examples of the discussion in popular media before and after the election.

${ }^{10}$ Discussion and inclusion of improvisation in music education scholarship and classroom practice increased significantly over the last 20 years (Sarath 2002, 2013, Burnard 2000, Dunbar-Hall and Wemyss 2000). Within the Western classical ensemble paradigm, however, improvisation does not play a significant role. Students accustomed to musics that draw continually on improvisatory practices including, for example, rap battles, do not necessarily find their musical practices validated by the types of improvisation that may occur in a Western classical ensemble context.

${ }^{11}$ See http://www.musicalfutures.org for further information.

${ }^{12}$ Elpus and Abril (2011) found that $65.7 \%$ of the $21 \%$ of high school seniors who participated in music in the U.S. in 2004 were White.

${ }^{13}$ The data I have entirely relates to K-8 school settings, thus I cannot make specific implications for secondary school music. I do think that teachers could adapt much of what was successful at the K-8 level for secondary students.

${ }^{14}$ All names are pseudonyms.

${ }_{15}$ Students in Grade 3 in Canada are eight or nine-years-old.

${ }^{16}$ Mitchell Robinson routinely uses case studies with second-year students in Principles of Music Education. I have adopted this practice, as it is successful in getting students to think critically about difficult issues in a collaborative and supportive way.

17 Elpus (2015) conducted a demographic profile of music teacher licensure candidates in the United States and found that $86.02 \%$ of teacher candidates seeking licensure in the U.S. were White. This white demographic is thus prevalent in postsecondary music education programs. 
18 The article drew on Bonilla-Silva's (Bonilla-Silva 2006) "minimization of racism" frame (28-9).

${ }^{19}$ See the Southern Poverty Law Center's website for further information on the term at https://www.splcenter.org/fighting-hate/extremistfiles/ideology/alternative-right.

${ }^{20}$ I again direct the reader to "Hatewatch" provided by the Southern Poverty Law Center (https://www.splcenter.org/hatewatch).

${ }^{21}$ See endnote 1 for data on the increase in hate crimes in the U.S. since the 2016 election of Donald Trump. 